\title{
Stadtmuseen als kulturelle Praxis. Zur Geschichte eines bürgerlichen Phänomens
}

Abstract: Die Beschäftigung mit bürgerlichen Sammlungen in Niederösterreich im langen I9. Jahrhundert rückt eine regionale Geschichts- und Wissenschaftskultur als Teil der kulturellen Praktiken ins Bild, die eine zunehmend heterogene bürgerliche Gesellschaft einigte. Die ältesten bürgerlichen Sammlungen waren bis um die Mitte des I9. Jahrhunderts in ihren Beständen und ihrer Präsentation noch an den Idealen der Aufklärung orientiert. Sie unterschieden sich somit kaum von den adeligen und klösterlichen Sammlungen jener Epoche. Hingegen legten niederösterreichische Stadtmuseen ab der zweiten Hälfte des i9. Jahrhunderts ihren Fokus auf die Darstellung lokaler Geschichte. Auf diese Weise erzeugten, stabilisierten und repräsentierten Stadtmuseen bürgerliche Identität. Sie spiegeln dadurch die emanzipatorischen Bestrebungen des kleinstädtischen Bürgertums wider. Gleichzeitig lassen sich jedoch Einflüsse der alten Eliten aus Adel und Klerus, den Repräsentanten einer ständischen „höheren“ Kultur, ausmachen. Das zeigte sich vor allem in den Kontakten zu den Wiener Gelehrtengesellschaften.

Municipal Museums as Cultural Practice. On the History of a Bourgeois Phenomenon. Research on the history of bourgeois collections in Lower Austria in the long I $9^{\text {th }}$ century turns its attention to a regional culture of science and historiography that formed part of the cultural practices that united the increasingly heterogeneous middle classes. Until the mid-I $9^{\text {th }}$ century, the oldest bourgeois collections were still guided by the ideals of the Enlightenment and hence they closely resembled the contemporary aristocratic and monastic collections. In the second half of the $19^{\text {th }}$ century, the municipal museums focussed on exhibiting local history. Thus municipal museums created, stabilised and represented the identity of the provincial middle classes (Bürgertum) and reflected their emancipatory ambitions. Nevertheless, the elites of the society of orders, the nobility and the clergy, still exerted considerable influence, particularly via the learned societies at the time.

Keywords: cultural practice, museum history, history of collecting, middle classes, voluntary associations

doi.org/10.52035/noil.2021.19jh02.22

Veröffentlicht nach externer Begutachtung (doppelblind) / published after external peer review (double blind) 